УДК 615.43.582.635.5(571.15)

\title{
ИЗУЧЕНИЕ САПОНИНОВ В ПОДЗЕМНЫХ ОРГАНАХ ФЕРУЛЫ ХЕРМОНСКОЙ
}

\author{
(C) Л.М. Федосеева, Дали Балтах Башар* \\ Алтайский государственный медицинский университет, пр. Ленина, 40, \\ Барнаул, 656054 (Россия), e-mail: sus@agmu.ru, bashar09@mail.ru
}

\begin{abstract}
Проведено исследование сапонинов подземных органов ферулы хермонской (Ferula hermonis Boiss.) семейство зонтичные (Apiaceae), произрастающей на горе Хермон в Сирии.

Сапонины широко распространены в природе, встречаются в растениях различных климатических зон и имеют широкий спектр фармакологический активности. Важные свойства сапонинов: способность регулировать водносолевой обмен, оказывать противовоспалительное действие, снижать уровень холестерина в крови, кроме того, они обладают иммуномодулирующим, цитостатическим и цитотоксическим действием на клетки злокачественных опухолей, снижают уровень сахара в крови при сахарном диабете второго типа. Олеаноловая кислота проявляет гепатопротекторную и противовирусную активность (ВИЧ, вирус Эпштейн-Барра, вирусы гриппа А и Б). В результате проведения качественных реакций обнаружены тритерпеновые сапонины. После кислотного гидролиза в системе: кислота уксусная ледяная - кислота хлористоводородная - вода очищенная $(3,5: 1: 5,5)$ методом тонкослойной хроматографии проводили разделение суммы сапонинов в системе бензол - ацетон $(3: 1)$. Идентифицирована олеаноловая кислота, что подтверждено методом спектофотометрии после реакции сапонинов с кислотой серной концентрированной по характерному максимуму при 310 нм, определено количественное содержание суммы сапонинов в пересчете на олеаноловую кислоту, которое составило 7,27-8,49\%. Таким образом, сапонины подземных части ферулы хермонской являются перспективным объектом для дальнейших исследований.

Ключевые слова: Ferula hermonis, корень, сапонины, олеаноловая кислота.
\end{abstract}

\section{Введение}

Род Ферула (Ferula) содержит около 185 видов, которые широко применяются в народной медицине при различных заболеваниях [1]. Ферула хермонская (Ferula hermonis Boiss.) семейство зонтичные (Apiaceae) - используется на Востоке для повышения потенции, лечения заболеваний легких, сахарного диабета, обладает антиоксидантной и антимикробной активностью. Изучение химического состава корней ферулы хермонской в основном было направлено на определение сесквитерпеновых лактонов и их сложных эфиров [2-4].

Цель настоящего исследования - изучение качественного состава сапонинов в подземных органах ферулы хермонской и определение их количественного содержания.

\section{Экспериментальная часть}

Для исследования использовали подземные органы феруль хермонской, собранные в конце августа начале сентября 2009-2011 гг. на горе Хермон в Сирии.

Для проведения качественных реакций готовили водное извлечение в соотношении 1:10 и проводили следующие реакции: реакция пенообразования, реакция Лафола, с раствором свинца ацетата и др. [5].

Для подтверждения результатов качественных реакций дальнейшую идентификацию сапонинов

Федосеева Людмила Михайловна - доктор фармацевтических наук, профессор, заведующая кафедрой фармацевтической химии с курсом органической и токсикологической химии Дали Балтах Башар - аспирант, e-mail: bashar09@mail.ru осуществляли методом тонкослойной хроматографии на пластинках «Sorbfil» в различных системах растворителей: гексан - этилацетат (2:1), хлороформ - этилацетат (9:1), петролейный эфир - хлороформ - кислота уксусная $(10: 4: 0,4)$, бензол -

\footnotetext{
* Автор, с которым следует вести переписку.
} 
ацетон (3 : 1). Извлечение БАС из сырья проводили с использованием в качестве экстрагента 70\% этилового спирта. Далее осуществили гидролиз для определения агликонов сапонинов: из полученного извлечения отбирали аликвоту объемом 10 мл и выпаривали досуха. Остаток растворяли в 10 мл смеси: кислота уксусная ледяная - кислота хлористоводородная - вода очищенная $(3,5: 1: 5,5)$, помещали в круглодонную колбу и нагревали на водяной бане в течение 2 ч. Затем гидролизную смесь разбавляли водой очищенной в соотношении $1: 2$, выпавший осадок отделяли фильтрованием. Осадок на фильтре промывали водой очищенной, растворяли в 25 мл 95\% спирта этилового.

В качестве свидетеля использовали СО кислоты олеаноловой («SIGMA Aldrich», CША).

После хроматографирования влажные пластинки обработали 20\% раствором серной кислоты, высушивали в сушильном шкафу в течение 8-10 мин при температуре $110{ }^{\circ} \mathrm{C}$. Зоны адсорбции веществ тритерпеновой природы и СО должны иметь окраску розово-вишневого цвета, переходящую в голубой $[6,7]$.

Определение содержания суммы тритерпеновых сапонинов проводили спектрофотометрическим методом после реакции взаимодействия с концентрированной серной кислотой. Тритерпеноиды протонируются по двойной связи с образованием карбокатиона, а при наличии карбоксильной группы при С-28 имеет место последующая лактонизация. При этом наблюдается характерный максимум поглощения при 310 нм [8].

Для проведения СФМ готовили извлечение следующим образом: около 2,0 г измельченного сырья (точная навеска) помещали в колбу вместимостью 250 мл, пятикратно экстрагировали 70\% этиловым спиртом порциями по 50 мл на кипящей водяной бане в круглодонной колбе на 200 мл с обратным холодильником. Полученные извлечения фильтровали и объединяли в мерную колбу на 250 мл, недостающий объем восполняли экстрагентом (раствор А). Далее из полученного извлечения отбирали аликвоту объемом 10 мл и выпаривали досуха. Гидролиз проводили по методике, описанной выше. Осадок на фильтре промывали очищенной водой, растворяли в 25 мл 95\% спирта этилового и собирали в мерную колбу на 25 мл (раствор Б).

К 1 мл полученного раствора Б прибавляли 4 мл очищенной серной кислоты, выдерживали 10 мин и определяли оптическую плотность на спектрофотометре VARIAN CARY - 50 в кюветах с толщиной поглощающего слоя 10 мм в области 220-450 нм. Раствор сравнения - концентрированная серная кислота.

Параллельно снимали оптическую плотность стандартного раствора кислоты олеаноловой.

Приготовление стандартного раствора кислоты олеаноловой: 0,004 г кислоты олеаноловой растворяли в 10 мл 95\% этилового спирта.

Полученные результаты обрабатывали с использованием параметрического критерия Стьюдента согласно ГФ ХІ [9].

\section{Обсуждение результатов}

Качественные реакции на сапонины дали положительные результаты на наличие тритерпеноидных сапонинов в корнях ферулы хермонской (табл. 1).

Результаты качественных реакций подтверждены методом ТСХ в системе бензол - ацетон (3: 1). После хроматографирования спиртового извлечения появилось 4 пятна голубовато-фиолетового цвета со значениями $\mathrm{R}_{\mathrm{f}}$ : 0,58; 0,$66 ; 0,75 ; 0,83$. Извлечение после гидролиза имело одно пятно, совпадающее по окраске (розово-вишневое, переходящее в голубой), и значению $\mathrm{R}_{\mathrm{f}}(0,5)$ со стандартом олеаноловой кислоты (табл. 2$)$.

Далее проводили спектрофотометрию. Тритерпеновые сапонины идентифицировали по характерному максимуму при 310 нм. Полученные спектры сапонинов и стандарта олеаноловой кислоты после их реакции с концентрированной серной кислотой представлены на рисунке. Количественное содержание суммы сапонинов рассчитывали по закону Бугера-Ламберта-Бера в пересчете на олеаноловую кислоту (табл. 3).

Таблица 1. Результаты качественных реакций сапонинов в корнях ферулы хермонской

\begin{tabular}{c|l|c}
\hline $\begin{array}{c}\text { № } \\
\text { п/п }\end{array}$ & \multicolumn{1}{|c}{ Реакция } & Извлечение / результат \\
\hline 1 & $\begin{array}{l}\text { Реакция пенообразования с растворами гидроксида натрия и хлористо- } \\
\text { водородной кислотой }\end{array}$ & Образуется пена, равная по объему и \\
2 & Реакция с раствором свинца ацетата 10\% & стойкости \\
3 & Реакция Лафона & Творожистый осадок \\
5 & Реакция с раствором нитрита натрия 10\% & Коричнево-зеленый осадок \\
& Реакция со спиртовым раствором холестерина $1 \%$ & Окрашивания не наблюдалось \\
\hline
\end{tabular}


Таблица 2. Результаты идентификации сапонинов в корнях ферулы хермонской методом ТСХ в системе бензол - ацетон ( $3: 1)$ до и после гидролиза

\begin{tabular}{c|c|c|c}
\hline Значение $\mathrm{R}_{\mathrm{f}}$ & Спиртовое извлечение & Спиртовое извлечение после гидролиза & Кислота олеаноловая \\
\hline $0,83 \pm 0,01$ & Голубовато-фиолетовый & - & - \\
$0,75 \pm 0,01$ & Голубовато-фиолетовый & - & - \\
$0,66 \pm 0,01$ & Голубовато-фиолетовый & - & - \\
$0,58 \pm 0,01$ & Голубовато-фиолетовый & - & Розово-вишневый, переходящий \\
$0,50 \pm 0,01$ & - & в голубой & Розово-вишневый, переходящий \\
& & & в голубой \\
\hline
\end{tabular}

Спектры поглощения сапонинов и олеаноловой кислоты в корнях ферулы хермонской: 1 - сапонины после гидролиза; 2 - олеаноловая кислота

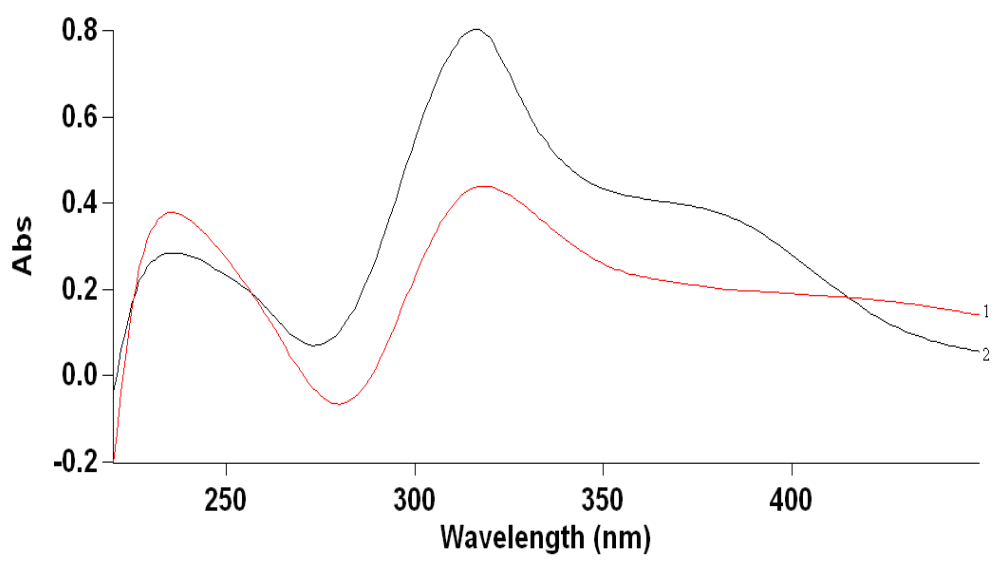

Таблица 3. Результаты определения суммы сапонинов в корнях ферулы хермонской в пересчете на олеаноловую кислоту

\begin{tabular}{c|c|c|c}
\hline \multirow{2}{*}{ Год сбора сырья } & \multirow{2}{*}{ Содержание сапонинов, \% } & Метрологические характеристики $\left(\mathrm{n}=5, \mathrm{P}=95 \%, \mathrm{t}_{\mathrm{p}}=2,78\right)$ \\
\cline { 3 - 3 } & & $\mathrm{S} \overline{\mathrm{X}}$ & $\mathrm{E}, \%$ \\
\hline 2009 & $7,27 \pm 0,13$ & 0,0586 & 2,23 \\
2010 & $7,34 \pm 0,14$ & 0,0652 & 2,47 \\
2011 & $8,49 \pm 0,14$ & 0,0630 & 2,06 \\
\hline
\end{tabular}

В результате проведения количественного определения содержания суммы сапонинов в корнях ферулы хермонской, установлено, что в пересчете на олеаноловую кислоту оно составило 7,27-8,49\%.

\section{Вивьды}

В результате проведенных исследований подземнных органов ферулы хермонской обнаружили наличие сапонинов тритерпеновой группы.

Методом ТСХ и спектрофотометрии идентифицировали олеаноловую кислоту.

Количественное содержание суммы сапонинов в пересчете на олеаноловую кислоту составило 7,27$8,49 \%$.

\section{Список литературы}

1. Pimenov M.G., Leonov M.V. The Asian Apiaceae biodiversity database (ASIUM) with particular reference to southwest Asian taxa // Turkish journal of botany. Turkey, 2004. Vol. 6. Pp. 139-145.

2. Auzi A. A., Gray A.I., Salem M.M., Badwan A.A., Sarker S.D. Feruhermonins A-C: three daucane esters from the seeds of Ferula hermonis (Apiaceae) // Journal of Asian Natural products Research. China; Japan; Korea and India. 2008. Vol. 10. Pp. 701-707.

3. Abourashed E.A., Galal A.M., El-Feraly F.S., Khan I.A. Separation and quantification of the major daucane esters of Ferula hermonis by HPLC // Planta Medica. 2001. Vol. 67. Pp. 681-682.

4. Diab Y., Dolmazon R., Bessie're JM. Daucane aryl esters composition from the Lebanese Ferula hermonis Boiss (zallooh root) // Flavour and Fragrance Journal 2001. Vol. 16. Pp. 120-122.

5. Ковалев В.Н., Попова Н.В., Кисличенко В.С. и др. Практикум по фармакогнозии: учебное пособие для вузов. Харьков, 2004. 512 c. 
6. Евтушенко Н.С., Багирова В.Л., Шлянкевич А.М. Исследование хроматографического поведения моно- и бициклических терпеноидов с целью выбора оптимальных условий хроматографирования препаратов их содержащих // Современные методы анализа фармацевтических препаратов: сб. науч. тр. ВНИИФ. М., 1988. Т. 26. C. $76-81$.

7. Сур С.В. Методы выделения, идентификации и определения терпеновых соединений // Химикофармацевтический журнал. 1990. №5. С. 45-50.

8. Писарев Д.И., Мартынова Н.А., Нетребенко Н.Н., Новиков О.О., Сорокопудов В.Н. Сапонины и их определение в корневищах аралии маньчжурской в условиях Белгородской области // Химия растительного сырья. 2009. №4. С. 197-198.

9. Государственная фармакопея СССР. Вып. 1. Общие методы анализа. М., 1987. 334 с.

Поступило в редакичию 18 октября 2013 г.

После переработки 12 марта 2015 2.

\section{Fedoseeva L.M., Dali Baltah Bashar*. STUDY OF SAPONINS IN ROOTS OF FERULA HERMONIS}

Altai State Medical University,pr. Lenina,40,Barnaul,656054 (Russia),e-mail:sus@agmu.ru, bashar09@mail.ru

The study of saponins from Ferula hermonis roots, belongs to the family Umbelliferae, growing on Mount Hermon in Syria, was undertaken. Saponins widely distributed in nature, encountered in plants of different climatic zones and have a wide range of pharmacological effects. Important properties of saponins: the ability to regulate water-salt metabolism, has Antiinflammatory effect, reduce blood cholesterol levels, moreover, they possess immunomodulatory, cytostatic and cytotoxic effects on malignant tumor cells, reduce blood glucose levels in diabetes mellitus type 2. Oleanolic acid manifests hepatoprotective and antiviral activity (HIV, Epstein-Barr virus, influenza viruses A and B).

As a result of qualitative reactions, was detected a existence of triterpene saponins. Then, after acid hydrolysis in: glacial acetic acid - hydrochloric acid - Purified water $(3,5: 1: 5,5)$, using the method of thin layer chromatography, separation of saponins was carried out in the benzene-acetone $(3: 1)$, Oleanolic acid was identified. Results were confirmed by Spectrophotometry, after a reaction of saponins with concentrated sulfuric acid, by the characteristic maximum at $310 \mathrm{~nm}$, the quantity of the content of saponins was defined, equivalent to oleanolic acid is equaled $7,27-8,49 \%$.

Thus, saponins underground part of the Ferula hermonis is a promising target for future research.

Keywords: Ferula hermonis, root, saponin, oleanolic acid.

\section{References}

1. Pimenov M.G., Leonov M.V. Turkish journal of botany. 2004, vol. 6, pp. 139-145.

2. Auzi A. A., Gray A.I., Salem M.M., Badwan A.A., Sarker S.D. Journal of Asian Natural products Research. 2008, vol. 10, pp. 701-707.

3. Abourashed E.A., Galal A.M., El-Feraly F.S., Khan I.A. Planta Medica. 2001, vol. 67, pp. 681-682.

4. Diab Y., Dolmazon R., Bessie're JM. Flavour and Fragrance Journal, 2001, vol. 16, pp. 120-122.

5. Kovalev V.N., Popova N.V., Kislichenko V.S. i dr. Praktikum po farmakognozii. Uchebnoe posobie dlja VUZov. [Workshop on pharmacognosy. Textbook for High Schools]. Har'kov, 2004, 512 p. (in Russ.).

6. Evtushenko N.S., Bagirova V.L., Shljankevich A.M. Sovremennye metody analiza farmacevticheskih preparatov: sbornik nauchny trudov VNIIF. [Modern methods of analysis of pharmaceuticals: collection of scientific papers VNIIFK]. Moscow, 1988, vol. 26, pp. 76-81. (in Russ.).

7. Sur S.V. Himiko-farmacevticheskij zhurnal, 1990, no. 5, pp. 45-50. (in Russ.).

8. Pisarev D.I., Martynova N.A., Netrebenko N.N., Novikov O.O., Sorokopudov V.N. Himija Rastitel'nogo Syr'ja. 2009, no. 4, pp. 197-198. (in Russ.).

9. Gosudarstvennaja farmakopeja SSSR. Vyp. 1. Obshie metody analiza. [The State pharmacopoeia of the USSR. Vol. 1. General analysis methods]. Moscow, 1987, 334 p. (in Russ.).

\footnotetext{
* Corresponding author.
} 